Ceremonial Performances Pertaining to Birth, as Performed by the Maori of New Zealand in Past Times.

Author(s): Elsdon Best

Source: The Journal of the Royal Anthropological Institute of Great Britain and Ireland, Vol. 44 (Jan. - Jun., 1914), pp. 127-162

Published by: Royal Anthropological Institute of Great Britain and Ireland

Stable URL: http://www.jstor.org/stable/2843534

Accessed: 29-01-2016 14:04 UTC

Your use of the JSTOR archive indicates your acceptance of the Terms \& Conditions of Use, available at http://www.jstor.org/page/ info/about/policies/terms.jsp

JSTOR is a not-for-profit service that helps scholars, researchers, and students discover, use, and build upon a wide range of content in a trusted digital archive. We use information technology and tools to increase productivity and facilitate new forms of scholarship. For more information about JSTOR, please contact support@jstor.org.

Wiley and Royal Anthropological Institute of Great Britain and Ireland are collaborating with JSTOR to digitize, preserve and extend access to The Journal of the Royal Anthropological Institute of Great Britain and Ireland. 


\title{
CEREMONIAL PERFORMANCES PERTAINING TO BIRTH, AS PERFORMED BY THE MAORI OF NEW ZEALAND IN PAST TIMES.
}

\author{
By Elsdon Best, Dominion Museum, Wellington, N.Z.
}

The ritual of the old-time religion of the natives of New Zealand has attracted some attention from writers, albeit we do not possess a great deal of detail on the subject. The causes of this paucity of information are twofold. In the first place the natives who possessed the knowledge of such details were chary of imparting information concerning them to the intrusive Europeans, for your Maori is ever conservative in these matters; in the second place, we have had but a very limited number of collectors in the field, and the majority of these have practically confined their attention to the collection of historical traditions and myths; few have turned their attention to the rites and customs of the Maori, matters that are of much greater interest than the modern history of the people, so much of which has been collected and published.

Of the many works written concerning the Maori folk, a very considerable number has been produced by persons who have not collected any information thenselves, and have merely copied from other writers with wearying frequency. We are also developing a class of authorities, innocent of any knowledge of the Maori, his language, mentality, customs and religion, who yet lay down the law on these subjects with a confidence that is little less than sublime. Yet the matter published consists either of theories, or is copied, copied, and again copied. An original worker is as an oasis in the wilderness.

Again, writer after writer of this class has been telling us for a number of years past, that it is impossible to collect matter concerning the old-time customs, rites, etc., of the Maori people, that all the men of knowledge have long passed away, none remaining save the blank-minded. A modern writer remarks on "the impossibility of procuring reliable information on the details of this subject, such as the seasons for certain fish, the marks for fishing grounds, the technical names for the parts of fish hooks, etc., and traps, and more minute details of the art in general." Now all this is purely imaginary, though we admit its difficulty in the case of a writer who does not understand the Maori language, and never makes any serious attempt to collect such information. That information could be got now by any person who can converse freely with natives, who can gain their confidence, who uses a little tact, and does not antagonise the Maori, as an acquaintance of ours lately did by paying one at the rate of a shilling an hour for certain information concerning the customs, etc., of his forefathers. 
We have been told repeatedly that no living Maori has any knowledge of the highest form of religion known to that people formerly, namely, the Cult of Io. Yet, in a district lately visited by the writer of these notes, he encountered no fewer than five old men who are acquainted with much of the ritual pertaining to that cult, and who also possess a vast amount of information on the old time customs, religion, mythology, technology, etc., of their race.

In proof of this statement, which we opine will be assailed by some of our friends, we give below a detailed account of the ceremonial performances enacted on the occasion of the birth of the first child of a Maori family of rank, as performed in the days that lie behind. This matter was collected by us in the year of our Lord, 1913, having been dictated to us in the Maori tongue by Te Whatahoro, of Wai-rarapa, a man seventy-three years of age, who has a great store of knowledge in comnection with his people. We hope, at some future date, to publish it in the original, for it is well worth it, but this would benefit Maori linguists only.

The information here given was taught by old men in the fifties and sixties of last century.

It must first be noted that the more elaborate ceremonies about to be described were not performed over all children, but only, as a rule, over the firstborn child, male or fernale, of a family of rank, of a chieftain of the upper class. In some cases a younger child might be so treated, or the first-born male and first-. born female child of a family. Younger children, and those of lesser rank, frequently had a modified form of the Tua or Toli rite performed over them, but children of the common class often had to get along without anything of the kind. The commoner form of the ceremony consisted principally of the dedication of a male child to the service of the god of war, and of a female child to the service of the tutelary deity, or presiding genius, of the tasks of women.

What made the higher form of the rite remarkable was the fact of the introduction into the ritual of the name of the Supreme Deity of the Maori raceIo the Parentless, Io of the Hidden Face.

Now it was in regard only to what he deemed the most important subjects and occasions, that the Maori ventured to address invocations to Io, or even to utter his name, and on no occasion was even his name mentioned on any ordinary occasion; only a few privileged persons of rank could attend such ceremonial performances. The name of Io was held in awe and respect to an extent that cannot be grasped by us, and the Maori of the early days of European settlement heard with amazement and contempt our name for the Supreme Being used in execration, and even in tones of pleasantry. Such an attitude was an impossibility among the Maori people.

All this goes to show the importance, from the Maori point of view, of the ritual pertaining to the ceremonies about to be described, and it will be well for the reader if he can adopt that view for the time being, and not bear in his mind's eye the spectaele of our christening ceremony, or even of a confirmation service. 
The ceremonial matter given in this paper is as it was performed on the east coast of the North Island up to about the middle of last century. In other districts, such rites differed to some extent, hence we do not include any account of these, lest confusion overtake our readers.

In a speech made to his pupils some fifty years ago, Nepia Pohuhu, one of the last teachers of the tapu lore of the Maori, explained why such lore should not be divulged to Europeans, and how it was that missionaries were not allowed to become acquainted with it. The old man who gave us the following notes stated that a renowned missionary on the east coast had endeavoured to obtain an account of this ritual, but that the natives who were acquainted with it decided to withhold it, for reasons obvious to those who know the native mind, and the attitude of the average missionary towards such matters. Our old friend wound up with the remark :-

"Some isolated incidents of this ritual have indeed been divulged to Europeans, but never the ceremonial in its entirety. Now, for the first time, a white man has gained the full account. Kua riro haepapa atu $i$ a koe, e hara i te riro tärä."

All of this goes to show that, when you wish to gain an insight into the occult lore of the Maori, it is not desirable to go to him as a missionary; also that you should treat his beliefs with respect; nor try to force your own upon him; and that it is a wise thing to imitate his dignity and politeness, and treat him as you would one of your own folk whose knowledge exceeds your own, and whom you look upon as a master. Having concluded which homily, doubtless a tedious one, we proceed to our subject, with the preliminary remark that we include some explanations made in reply to queries on our part.

\section{CONCEPTION.}

When a woman of the high chieftain class of which we are writing was known to have conceived, she was not allowed to perform any laborious work; more especially was she forbidden to carry any food-products on her back (the common native way of carrying burdens), inasmuch as such an act would have a most injurious effect upon the unborn child, for, be it known, such a child is tapu even before birth. The proximity of food-products has ever a desecrating or polluting effect upon tapu persons, objects, or places.

Hence it was that such a woman of the ariki class was provided at this time with two female attendants, termed tapuhi, selected from her own relatives, who were in constant attendance upon her until the birth of the child, and indeed for some time after. Their duties included those of the midwife and nurse, hence the name of tapuhi applied to them, from the verb tapuhi,-to nurse, to tend in sickness, etc. A comparative stranger, or one not nearly related to the woman, might, if so employed, work some harm to her, or to the child. The Maori world VOL. XLIV. 
was full of unseen dangers not heeded by us: the malign influence of demons, the dread powers of magic, greatly affected Maori thought and action.

The news of the conception of our wahine ariki would be received with joy by her near relatives, and indeed with much gratification by the people generally, for the members of the ariki class formed a division of the commune, albeit the figureheads thereof; they belonged to the people. Such persons were treated with the highest respect, save in exceptional cases when a member showed himself, or herself, unworthy of it.

The news of her conception would also add to the fame of the woman, and cause her to be talked about, a matter of no small moment in a Maori community. But, above all, it proved that she was capable of bearing children hei kahaki $i$ te Kawai, to perpetuate the line of descent.

Conception, the acquisition of form by the fotus, is termed kunenga, and the wise men of old maintained that the eyes were the first parts to acquire form, then the head, and then other parts. It was Io, the Supreme Being, who gave to wroman the power to bear children; without this power no woman would be fruitful. In regard to the functions of sex, it was taught of old that the seed of man is with the male, and the sheltering haven with the female; the male has the kernel provided by the Deity, while the female shelters the same, and nurtures it, hence the growth of all things. For, indeed, the female is a copy of the male. The seed (of man) emanated from Io of the Hidden Face.

During the period of conception it often occurred that a woman would strongly desire a change of food, and would express a wish for a certain article of food, such as a bird, in which case her husband would make every endeavour to procure it for her. Such food was said to provide milk for the child, hence it was termed a whakawaiu. Thus it was that Rua-here-tieke, daughter of the famous chief, Kahungunu, received her name, her mother, at such time, having been fed on the birds known as tieke, that were caught in a hole in a hollow tree.

One Hine-te-iwaiwa was looked upon as a kind of tutelary goddess of childbirth, as well as of all tasks performed by women. As iwa means nine, her name is rendered by some as "The Lady of the Nines," and the name is thought to be connected with the period of gestation in woman. This, however, seems to be but a guess. She was certainly invoked in childbirth, and some writers identify her with Hina or Sina, the personified form of the moon. Now, regarding the singular neck-pendant worn by Maori women, and termed a heitiki, often fashioned from nephrite, and which, although of human form, has the head sideways and the legs doubled up, it is known to every old native that this pendant is, properly, worn by women only, and herein lies the story of its origin. It is highly probable that this curious figure represents the human fœtus or embryo, as indeed some old natives state, and that the wearing of it by women is a survival of, or allied to, certain acts connected with phallic symbolism of long past centuries. The figures were ever most highly prized by the Mauri folk. One lately presented to the narrator is fashioned out of a whale's tooth, and is highly polished. 
Now the origin of the heitiki in Maori myth is as follows: The first one known was made and given to Hine-te-iwaiwa by her father, and as she is the presiding genius of childbirth, the conclusion come to above seems fairly clear.

There are many beliefs and curious superstitions connected with conception and birth. For instance we know that, in former times, when natives crossed Cook Straits, any person making the trip for the first time was obliged to cover his eyes (some say that all persons had to veil their eyes), also the carved images at the bow and stern of the canoe had to be covered, lest the people looked upon the thrice tapu rock known as Nga Whatu. Should any person look upon it, then assuredly would disaster overtake that vessel, paddle the crew never so bravely. Also, that any women in the canoe who had conceived, were obliged not only to cover their eyes, but also closely to enshroud their abdomens.

\section{Rite to Cause Conception.}

In former times the Maori tohunga, or priests, occasionally performed a very singular rite over women who had, so far, proved to be sterile. So far as we can judge, this condition did not often obtain in pre-European times, though somewhat common now. As the details of the ceremony are of some interest, we here insert them. It stands as another proof of the faith of the Maori in his gods. We have collected two accounts of this ceremony, one as performed over women of rank by a priest of the higher order, and another as performed by priests of a lower class, the same being shamanistic in its details. It is the former version that is related below.

When it was found, or feared, that a woman of the higher class was pulkupa, .or barren, then the matter was referred to the principal priest of the community for his direction and manipulation. His first action was to ask the parents which sex they desired the child to be. Having ascertained this somewhat important fact, he then procured a leaf, and, with a sharp flake of flint, or obsidian, he cut the leaf into the outline of the human form, marking the features, such as eyes, nose, and mouth on it, and also indicating the sex. The woman was then conducted to a tapu place, where a mat was spread on the ground, on which she lay face upward. The priest then recited certain formulæ that also entered into other rites, and are a very curious and interesting illustration of Maori ethics, inasmuch as their object was to remove all evil, worldly and extraneous influences from her, to "loosen" the effects of all undesirable things or influences that had ever affected her, so as to leave her body and mind in as pure a condition as possible, as also receptive. In this state she was compared to the first woman, Hine-ahu-one (the Earth-formed Maid), formed by Tane on the mons veneris of the Earth Mother in the days of the gods. For the breath of life that animated Hine, as also the wairua, or spirit, implanted in her, had been obtained from Io, the Supreme Being, and that Being was now to be invoked in order to render this subject fruitful, even as he had vitalised Hine, the mother of mankind, and caused her to conceive; in 
the days when the world was young, when gods alone held sway, and walked abroad, when man was not.

Having so prepared the subject, the priest, holding the leaf image in his hand, recited an invocation to Io to induce him to endow this woman with the mana (power) of Hine-ahu-one to conceive children, i.e., that the subject may become fruitful, and bear a male, or female child, as the case might be.

He then opened the woman's cloak and turned it back as far as her navel, exposing her body so far. Then, standing at her feet, facing her, and holding the leaf image in his left hand, he repeated these words:-

"This child is now

A disciple of thine, $\mathrm{O}$ Io !

Thy breath, the breath of Hine-ahu-one,

May it now alight."

Our translations are crude, but give the general meaning of the lines. Here we have an explanation of the views held by the old-time Maori priesthood. It was the supernatural power of Io, the Supreme Being, together with the wairua (spirit, soul) obtained from him, that vivified Hine-ahu-one, and endowed her with the power to bear children ; in like manner, such power was craved for the present subject.

At the conclusion of the recital of the above, the priest placed the leaf image, face downwards, upon the woman's body, between the navel and the lower end of the breast-bone, so that the head of the image was towards the woman's head. He then covered the woman's body, drawing the cloak over the leaf, and continued his invocation.

When the priest had finished his invocation, the ceremony was over, save the tapu lifting rite that freed the persons engaged from restrictions imposed by that condition. The priest would take the leaf away, carefully enfold it in a piece of pliable bark, put a wrapper round it, and deposit it at some tapu or forbidden spot. When that woman was about to be confined, he would take the leaf to the lying-in hut, and deposit it, without the woman's knowledge, beside her pillow. It would not be shown to her until the child was born.

According to Maori belief, the wairua (spirit, soul) of a child is implanted in the fœtus before birth, at the time when the eyes assume form, and they are the first parts so to gain form.

We may state, at this juncture, that there was also a peculiar ritual for the purpose of causing a woman's fruitfulness to cease, that she might cease to conceive. This ceremonial was termed Taupa or kokoti-uru. We have not learned the particulars of this rite, but a piece of stone was employed therein, and the woman was supposed to be made as sterile as the stone.

'There is a tradition, some thirty generations old, that when a certain ancestor named Ruarangi was born, he being a first-born child, the taupa rite was then

1 The breath of life is here meant, the vitalising principle. 
performed over his mother, lest she should bear a daughter later on, the desire being that of male descent only.

The Maori believes that the sex of a child can be ascertained prior to birth, at least in some cases. If the dark coloured parts of the woman's breasts are extensive, then the child is a female; if smaller but darker in hue, the child is a male.

It is a curious fact that the Maori folk believe that the unborn child receives nourishment through the fontanelles, which are called rua kai (food holes, or apertures). When these close up, the child can no longer receive nourishment within the womb, hence it begins to move and prepare for birth. In man, the hair growing on these parts is that plucked out to be used in divers ceremonies.

\section{The Whare Kohanga, or "Nest House."}

On account of the tapu pertaining to both birth and death, but few persons were ever born or ever died in a dwelling-house in Maoriland. In the case of the woman we are writing of, a special hut was constructed for her occupation during the period of parturition, and for some time after. Such a hut is usually alluded to as a whare kohanga, but, among the Takitumu folk, a more honorific name for it is whare puhi. This special hut was not of any elaborate workmanship, since it was destroyed when vacated by the lying-in woman and her attendants. In most cases it would be constructed of some form of thatching material, bulrushes or reed. It was not erected within the precincts of the village, but away from it, a temporary place built in some spot where there was no likelihood of its site ever being used for a good cultivation (see ante for remarks on the polluting and dishonouring effects of the proximity of food), such as a stony or sandy spot on the margin of a stream. At some distance from it, not too near, a rude cooking hut, or kitchen, was erected, whereat one or two women were located whose task was to prepare food for the confined woman and her two attendants. But no communication was allowed to take place between the two parties, or at least the members of one party were not allowed to approach those of the other. When food was prepared by the cooks for the whare lohanga party, it was carried to a spot between the two camps, and there deposited, the bearer returning to the cooking hut. When the bearer had so returned, then one of the tapuhi, or attendants, left the nest house, proceeded to the spot where the meal was deposited, and carried it to the hut, where the three women partook of it. We have even heard of cases in which a third bearer was employed, and it thus took three bearers, each with her own defined stage of progress, to convey the food to the "nest house" from the vile and tapu destroying precincts of the cooking shed. Such are some of the disabilities pertaining to the condition known as tapu, the primary meaning of which term is simply "forbidden." Tapu ever implies restriction in some form, or in many forms, as the case may be.

Only near relatives would visit the lying-in woman while she was in the "nest 
house"; these visitors remaining outside the hut; only the two attendants and the woman's husband being allowed to enter, save and except any priest whose duty was to perform some ceremony over the woman, such as will be described anon.

The "nest house" was made fairly comfortable, as far as the Maori idea of comfort goes, and in cool weather a fire was kept burning in it. This fire might be one of charcoal, or of some wood that does not make much smoke, kindled in a takuahi, the common native fireplace of dwelling-huts, consisting of a rectangular hole in the earthen floor, lined or bordered with four stones. But a better appreciated method of warming a "nest house" was that known as the ahi tu popoto. This was a singular contrivance, a form of stove that consumed itself. In this wise: a wide piece of bark of the kahikatea (Podocarpus dacrydioides) was procured and allowed to become dry, when it curls up into the form of a hollow cylinder (as is well known by us old bushmen). Several pieces of a bush vine were tied round this cylinder, and it was then set up in the earthen floor of the hut in an upright position. It was then filled with dry charcoal which, on being kindled at the top, burned slowly and steadily downward, emitting no smoke, the enclosing bark burning at the same rate as the enclosed charcoal. When all was consumed, it was replaced by another. Such a fire produces neither flame nor smoke, and considerable heat radiates from it. The lack of smoke is desirable, as it would injure the child's eyes.

A woman would adjourn to the "nest house" with her attendants when she felt her time was near, one of the signs being a numbed feeling in the small of the back. Her attendants, being near relatives, were sympathetic companions for her; she would not have anyone else near her at such a time.

We may state here that, after all ceremonial performances following the birth of the child had been duly performed, and the party had returned to the village community, then the "nest house" was destroyed. It was demolished and taken away piecemeal, together with any items, such as floor-mats, etc., used thereat, by a member of the priest class. Timbers, thatch, every item was conveyed by him to some place, probably the turuma or latrine, and there burned. The task of this man was to render the spot noa, common, or free from tapu, that is to take the tapu off it. In the execution of this function, which had its own special ritual, the parents, or the fathers of the parents of the child, would partake of food on the site of the "nest house." It would be highly improper for any unauthorized person to be the first to take food at such a place, or he might remark, in after days, "I was the first person to eat at the 'nest house' of so-and-so." This would be a belittling expression, and would assuredly cause trouble.

The tapuhi attend only to the woman, they have no other duties: they assist her in labour, and attend to the child. These tapuhi are often referred to as puhi, a term somewhat confusing, inasmuch as the same term was applied to a young woman of a leading family who had been brought up with special care, and treated with much distinction, having female attendants, and who was not allowed to perform any laborious work whatever. Again the word răŭhi is employed in a 
similar sense to tapuhi, a wahine rauhi being a woman who attends a sick persorr, or who tends and rears children other than her own. The expression rauhi is also applied to a chief whose conduct towards his tribe is marked by kindly feeling and consideration.

These tapuhi, or attendants were not allowed to visit their homes, it is said, during their stay in the Whare Kohanga, or indeed to go far from it, though the female cooks might do so.

\section{Parturition.}

When in labour the Maori woman kneels down, with her knees wide apart. An attendant "squats" down in front of and facing her, and the two clasp each other round the body, under the arms. The attendant puts her knees against the body of her charge just below the breast-bone, and presses them downwards in order to assist expulsion.

In the event of a woman being overtaken away from home, as when in the forest or elsewhere, and if alone, then she constructs, at least in some cases, a substitute for an attendant's knees in what is termed a pae whakaruru or pae whakairi. She obtains a pole and lashes it to two small trees in a horizonal position, at such a height from the ground that, when standing by it, the pole touches her body low down. Then, when in labour, she leans against the pole and so works her body against it as to obtain the desired pressure downward. In some cases, however, no such assistance is used.

Should a woman pass the seventh day from the time that the pains of birth or symptoms of approaching birth began, without giving birth to the child, it is known that there is something wrong. This is looked upon as the limit for easy, natural parturition, and the term rauru nui is applied to such a birth, or to the child (rauru is one of the names of the umbilical cord; nui implies bigness). This term is limited to the period of seven days.

Should the period of seven days be passed, it is then understood that trouble is toward, and probably the woman will give birth to twins. The term rauru whiwhia (entangled umbilical cord) is applied to such a belated birth. If the tenth day be passed without birth, then a materoto (miscarriage, stillborn child) is reckoned upon. Such a condition is called a marua-aitu (serious misfortune).

In cases of rauru whiwhia, it is said that either a leg or an arm of a child will appear first, and not the head ; in which case that child will turn out to be forward and disobedient, of a rebellious nature. In such cases one of the attendants would often thrust back the limb so appearing, an operation accompanied by a charm or invocation recited by the officiating priest, that individual being called in at such times of difficult parturition.

In these cases of difficult birth, a woman would sometimes be carried to the tuahu, or sacred place of the village community, at which many religious ceremonies were performed, and there the priest would repeat over her the following :- 
"Come, $\mathrm{O}$ maid, in the time of fullness ; bear thyself bravely before the world, even as your ancestors, Hine-titama, when trodden were the ways of earth and heavens, even the ascent to Tiritiri-o-Matangi. Strenuously pursue your course, the functions of your ancestors, Hine-ahu-one, to lie within Hui-te-rangiora. Bring thyself, O maid, to the world of life."

The references to the first human birth herein were supposed to be effective. Hine-ahu-one was the first mortal woman, the first female of the genus homo, formed by Tane, and, when endowed by life, married by him, their first child being Hine-titama, the first woman to be born. Hui-te-rangiora was the abode of Tane, and is a term implying calm, peacefulness. Tiritiri-o-Matangi is the name of the eleventh heaven; in the one above which, and the last, dwells Io, the Supreme Being.

The above is merely a paraphrase of the formula chanted by the priest over the young woman. He then repeats the following to cause the child to be born in a correct manner :-

"Now I appeal to the gods of earth and heavens that they may cause you to come forth to Tahuaroa, to this world. Come, $\mathrm{O}$ child: tread thy path, the broad way of Tane. Bring thyself by the way of your ancestors, of Hine-titama, who brought herself forth to this world, to dwell in peace within Hui-te-ana-nui. Content shall be thy lot in the world of Life and Light, and sighs of relief proclaim the ordeal past, O child."

Tahuaroa is a name sometimes applied to the earth; it is so used in song and myth. The "broad way of Tane" is the path or way by which the spirits of the dead pass on their way back to the fatherland of the race, the place where man originated, whence they pass down to the underworld, or ascend to the heavens, according to whether they sympathize most with the Earth Mother or the Sky Parent.

Hui-te-ana-nui is the dwelling-place erected by Tane and Tangaroa, two of the offspring of Rangi and Papa (Sky and Earth), for Hine-titama, daughter of the first woman, Hine-ahu-one (see ante).

Such was the mode of procedure in a case of difficult parturition, and our informant illustrates it by giving the tradition of a famous ancestress of his folk, of the Wai-rarapa district, to wit one Moe-te-ao, who flourished about ten generations ago, and whose twin sons became famed chiefs, albeit they had much difficulty in entering the world. One of them, Mahanga-tikaro, was partially born in an unusual manner, but was returned, as already explained. This occurred a second time, whereupon he was again put back, and the mother carried to the sacred place called Toka-a-Hinemoko. Here the other twin, Mahanga-puhua, was born, but not the first mentioned, hence the mother was carried to Te Wao-kairangi, where the second birth took place. That place has since been known as Nga Mahanga, or "The Twins."

In some cases a priest repeated, during parturition, a charm to cause the child 
to be born, in which occurred words expressing gratitude to the gods for their having given them a child. These words, however, seem to be principally addressed to Io, for all that enlightens man, the spirit, knowledge, and intellectual or spiritual welfare, all emanate from Io, the Supreme Being.

We now turn to some very curious notes furnished to our informant in the sixties of last century by one of the famed wise men of the east coast, some of the expressions in which are by no means easy to render into English. These remarks appear to treat of the mythical origin of birth, ere man appeared on the earth ; in fact they describe the birth of the offspring of the Sky Parent and the Earth Mother, and form a very singular and interesting myth.

Those who have studied Maori myths and Maori cosmogony are aware that the word Po is of frequent occurrence therein. It seems to be applied to the æons, or periods of time, prior to the appearance of the offspring of the primal parents, Sky and Earth, indeed to the period before those parents came into existence; hence the term is often translated as Chaos. The ordinary meaning of the word po in the vernacular is " night" (Cf. pour $i=$ dark, darkness). The name is also applied to the underworld, whither spirits of the dead go. On account of the name of Po being so applied to the underworld, an impression prevails that it is a gloomy realm of darkness, even native accounts being sometimes tinged with this view. But, on the other hand, traditions speak of it as a world of light, wherein spirits live much as they do in this world. It would appear that the term Po, as applied to the period before the offspring of Earth and Sky appeared, as also to the spirit world, or the period after death, was employed as implying the Unknown, the dim inscrutable past and future into which human eyes and human mentality peer in vain.

The myth relates that the children of the primal parents lay within the Earth Mother for a period of seven Po (one authority says six), which corresponds with the seven nights (the Maori counted time by the nights of the moon) of the rauru nui, or normal period of birth. At length these children saw a dim glimmer of light, such as a glow-worm emits at night. Then one of them crept from within the ahuru mowai (sheltered, calm haven; a term applied to the womb), and came forth from the Earth Mother. Finding the outer world a most desirable place, he turned to persuade the others to come forth; Tane and others agreed to do so, while Whiro and yet others decided to remain within the Earth Mother. This matter caused a stir within the haven, and these (as yet unborn) children began to move within the calm haven; which movements were continued for a period of seven Po (equalling the seven nights of the normal period of labour). Even so, on the night that the secretions of the Earth Mother were tinged with blood, most of these offspring came forth to the world, on the seventh night of their movements within the "calm haven." They found the outer world a truly desirable place, albeit already occupied by Wero-i-te-Niniti, Maeke and Kunawiri (personified forms of cold), hence they nestled close to the sides of their mother for warmth. These children of the primal parents thus born during the normal rauru nui period, were of a kindly, desirable disposition. But some of these offspring did not appear until the 
tenth night; these were Whiro, Uru, and others. Whiro especially appeared in a very peevish condition, irritated at Tane for leading them out of the Earth Mother to be assailed by cold. (Compare here the remarks on the raura whiwhia period of birth, supra.) From this time on, Whiro and Tane were enemies, and, in after times, when Whiro was defeated by Tane, the former retired to the underworld, that is he returned within the Earth Mother, with whom his sympathies lay. Whiro and others were the fractious, unruly children of the raura whiwhia, or belated birth period.

In Maori myth, Tane represents the male principle, as also, apparently, light, and, we are much inclined to think, the sun. Tane was the great generator, and the Maori fully grasped the powers of the sun in causing growth.

Each of the seven Po during which the movements of the above children continued, has its special name, the term Po being qualified by another word, e.g., the Po-uriuri, and we may note that four of these qualifying expressions denote phases of darkness. Having given the names of these $\mathrm{Po}_{0}$, the old priest continued : now if a child be born with the period of these Po, that child is said to be a rere matua, a rauru nui child, vigour and desirable qualities will be his. On the seventh night difficulties commence, and are greater on the eighth night (day). Labour has now become difficult, strenuous. If the event occurs on the Rakau-nui night (16th night of moon's age), or the Whiro night (1st day of moon's age), or in the Tangaroa nights (23rd, 24th and 25 th nights of moon), these are bad nights for a woman, she will have a strenuous time; she should be carried to the tuahu, where a priest should attend and save her. If the time of birth is in the commencement of the month, it is not well that it should be prolonged beyond the seventh or eighth night, for such is the rauru nui. Should it be prolonged to the ninth or tenth, then that is rauru whiwhia. These be the contentious, rebellious nights. An arm or leg may first appear, the body may be sideways, then, if care be not displayed, a dead woman, a dead child, result. Such an occurrence is termed a weu tapu; should that child be born, it belongs to Tu (god of war). Should the period of labour occur on the eleventh night, observe carefully the moon; if a Whiro (1st day of moon's age), then will the child be (born) living; nurture it carefully; for that is a rauru matua (see ante). Should the woman's time come during the Orongonui night (28th), study the moon, as to whether it is pale hued, or has a halo round it, for if the child selects the halo (is born at such time), then will it be a child of undesirable qualities. But if it selects the pale hued moon, or a pale red, then will it be a good child and all will be well with it. The twelfth night is an evil one, it pertains to Whiro, no child will survive.

Broadly speaking, and bringing the matter to a definite statement, the two series of Po seem to represent the periods of time before and after this life. When a Maori is questioned concerning some event that occurred before he was born, he is liable to reply thus-How can I tell; I was in the Po at that time. To the period after death, such terms as "the unseen Po," and " the untouchable Po," are applied, thus implying that they are beyond human ken. This series represents the ages 
of time that lie before the human soul after it leaves the body, the eternity of time in the spirit world, not of punishment or suffering, for that is a missionary teaching, but of calm and placid existence. But both periods are alike dark, in the sense of being unfathomable to the human mind; for no one has returned from the spirit world since the days of Mataora, the "broad way of Tane" is closed to all save the souls of the dead.

It is clear that the ancestors of the Maori, in common with other races, strove to fathom the unfathomable, in two directions, to peer into the past, to grasp the future. The above is part of the result, ideas evolved by a mythopoetic people, whose systems of cosmogony and anthropogeny teem with personifications of natural phenomena and objects, of intellectual power and spiritual supervision. Like unto our own ancestors, when true knowledge of such things was found to be unattainable, the Maori evolved myths to fill the place thereof. For, ever throughout the changing ages, the tale of many races, the human mind is as one.

The connection shown between the birth of the supernatural offspring of Earth and Sky, and that of man, is of interest, and is based on the belief that man is a descendant of the gods, of Tane and the "Earth-formed Maid," and that there is a spark of the divine in every man. Man is a descendant of the gods, but not of God, the Supreme Being; his connection with the latter, through Hine-ahu-one, lies in the fact that from Io came the spirit or soul, and the breath of life, by means of which Hine was vivified.

There is a common belief among some tribes that a male child is never born during an easterly or northerly wind; nor a female child during a south or west wind. This is probably connected with the fact that the term female is applied to the two first mentioned points, and that of male to the two latter. The fact that the more boisterous winds come from the west and south seems to offer an explanation of this curious nomenclature.

Return we from our digression. The umbilical cord is known by several names, as iho, pito, and rauru. Any items required at the time of birth of a child are prepared beforehand, and placed ready for use. For the purpose of tying the iho, or cord, the best material is said to be a piece of the pliant stem of a creeping plant known as makahakaha, that grows on sandy places, as on the sea coast. A piece of this has the outside scraped off, and is then formed into a small coil, when it is placed in water in order to keep it soft and pliable. Prior to its being required for use it would be put to soak in a small vessel of oil. In former times the oil obtained from the seed of the titoki tree (Alectryon excelsum) was used for purposes connected with the cutting of the cord. A piece of the pliable, soft inner bark of the houhi tree (Hoheria populnea) was also prepared, to be employed as a bandage. 'The outer and innermost layers of bark were rejected, and the soft, thin, lace-like, but strong intermediate laminæ selected for the purpose. This also was placed in water to prevent dryness and harshness.

The iho or cord was cut with a sharp flint flake, the cutting edge of which had been ground keen on a piece of sandstone. In the case of a high-class family, such 
a flint knife might be retained for this use only, and passed down the generations as an heirloom. The principal attendant would perform the operation of cutting the cord, or possibly the grandmother of the child, if more adept. When doing so, the measure adopted was usually that termed the konui, that is the length of the first joint of the thumb, the cord being cut at that length from the body of the child, sometimes a little more. In some cases, however, the koiti was adopted, namely, the length of the little finger. This matter would be decided by an adept, and such might remark :- "This konui is too short ; let it be the koiti." The cord was tied close to the body by one of the attendants prior to the cutting, and oil smeared over it, after which a short piece of the soft houhi bark, also oiled, was placed over it, and secured by the soft bark bandage, which was tied round the child's body. This peculiar bark retains oil well ; but nowadays European fabrics are used.

The attendants examine the cord every day, and attend to it, as also to the washing of the child. In cases wherein sponge was not obtainable for the latter purpose, some Phormium tow was used. This tow was specially prepared, the object being to obtain a soft substance; the fibre was stripped from the leaf, scraped, soaked in water, and then scraped again so as to produce a fine soft tow, this being used as a sponge. The water was contained in a patua, a vessel formed in an ingenious manner from the bark of the totara tree (Podocarpus totara); it was warmed by means of placing hot stones therein.

A form of massage (romiromi) was performed on newly-born children, according to some natives. We have heard of cases, wherein a woman had no milk for her child, in which it was fed on the masticated flesh of young birds.

The placenta (whenua) is always buried, in former times at some spot near the latrine (turuma), or other avoided place, that the spot might not be trespassed on.

There is said to be a doubt as to the birth of twins, as they are said to change positions in some cases, hence a nail of finger or toe was often marked by the attendant, for purposes of identification. Some natives believe that the last born of twins will turn out to be the more robust of the two; others again say the opposite. It is probably more in connection with the last born of a family that the above belief holds good, and an old-time saying is "Te potiki whakchirahira"- the self-extolling youngest last born.

The period of seven days mentioned appears to include premonitory symptoms, and does not apply merely to the period of actual labour.

\section{The Korotngo Ceremony.}

We have now to describe three ceremonies that pertained to the newly-born child, supposing that it be the first-born child of parents belonging to a leading family. There was much less ceremonial in the case of any other children born to the couple later on. The Maori was ever an upholder of the dignity and rights of primogeniture. The first of these ceremonial performances was the Koroingo or 
Maioha, the greeting or welcoming of the child. The second was the Tohi, or baptism of the child, and the third was the Pure.

When the birth of the child was made known to the clans, or family groups, of the father and mother of the child, a meeting of the sub-clans nearly related to them was arranged. That meeting was called for the purpose of congratulating the parents (and relatives) on the birth of the child, and in order that the people might express their gratification at the occurrence, which meant much to a communistic folk. This assembly would take place after the tasks pertaining to birth had been performed, but prior to the falling off of the pito or cord. The people assembled at the "nest house," outside of which, but in the porch thereof, the mother seated herself. The child was laid on a cloak and placed in the mother's lap, the latter facing the assembled people. The child was placed in her lap with its head resting against her body, so that it also faced the people.

In the case of a male child a considerable number of gifts would be made to it, more so, apparently, than in the case of a female. The bulk of such gifts would consist of food-products, which, though consumed by the mother, were always spoken of as being for the child; they were intended as a whakawaiu, i.e., to form milk for the child, to cause the mother to have a plentiful supply of the same.

The presents made by the relatives of the father of the child were deposited on the plaza, apart from those given by the mother's relatives, and the former were presented first, being deposited on the ground before the recipient, after the manner Maori. When this is done, then the first speaker rises, and his first remarks consist of congratulations, after which he greets, or welcomes the child. If this speaker be a member of the father's side of the house, he congratulates the mother's side; if a relative of the mother, he congratulates the father's side, after which he greets the child by repeating the following ancient composition :-

"Welcome, O son! (If a male child). That I may greet you, who come from the calm haven to cross the threshold of Huaki-pouri, as formed by Tane at the One-i-Kurawaka, whereat was shown the wondrous powers of the gods, the sacred power of the mother. Then gathers the blood within the womb, then formed are the eyes, and Rua-i-te-pukenga and Rua-i-tehorahora are acquired. Now moves the child, to appear as a lusty balue, as a fractious one, or as stillborn, passing through the narrow way to the outer world, forcing his way to the enduring world, O son !"

This paraphrase is but a poor rendering of the original, for we are sadly lacking in the divine afflatus. The crossing of the threshold of Huaki-pouri is scarcely a translation, but it implies the end of maidenhood and motherhood acquired.

The One-i-Kurawaka was the place where Tane formed the first woman on the mons veneris of the Earth Mother.

The sacred power of the mother is the power to bear children, with which the first woman was endowed by Io. Without this mana (power) woman could not bear children. 
The two Rua are personifications of knowledge; mentality, the soul, and power of thought that are now acquired.

After this greeting of the child, a ceremonial feast was held, the parents of the child eating the first portion of the food ere the company began to eat, a special basket of food being placed in the verandah of the hut for them. The rest of the people remained out in the open.

It is worthy of note that a man making a speech at such a function as this, would, on the completion of his speech, proceed to give an exhibition of his agility and powers of facial distortion, known as pikari and ngangahu, in which he pranced about, going through most amazing contortions, with glaring eyes and out-thrust tongue. This was looked upon as quite the proper thing to do, and was duly admired. It is but seldom seen now. Having finished this exhibition, he would repeat the recitation of the above effusion. This was always done among the Takitimu clans; it was considered unlucky to chant it but once.

After this, the following were chanted in the singular but euphonious monotone peculiar to the Maori :-

"Welcome, O son!

Hold fast to the sacred teaching; be quick and clear-minded to grasp the knowledge of heavenly and earthly matters, that such may be firmly retained, retained within thy mind be Rua-i-te-pukenga, Rua-i-te-horahora, and Rua-i-te-wanawana, as with Tane of old.

Welcome, $\mathrm{O}$ son!

Open be thy ears to listen, the ears of Rongomai-tahanui, of Rongomaitaharangi, of Tupai-whakarongo-wananga; and keep thy mind firmly on the Crown of the Heavens.

Now appears Poutu-i-te-rangi, and embraces Puke-hau-one, and Hine-rauwharangi stretch herself forth, while commences the work of husbandman. Formed be the many mounds, let the full mounds overflow; thine be the task, O Rongo-marae-roa. Hence the abundant harvest when Maruaroa marks the opening of the year, and luscious foods abound,-O son."

Here again the capering and grimacing performance is gone through.

One of the main objects of these singular effusions, semi-invocations as they are, teeming with references to world-old myths, was to cause a child to develop into a clear-minded, apt learner of the love of the gods, as well as of affairs connected with ordinary life. The above item contains many sacerdotal expressions, archaic and cryptic terms not met with in the vernacular, and the meaning of which is known to but very few natives now living; indeed, the meanings of some are unknown.

As observed before, the three Rua personify knowledge. The first mentioned personifies the acquisition of knowledge; the second implies the diffusion of knowledge, the power to teach, to point out right and wrong; the third stands for innate aptness, powers of observation, etc. Again, the qualifying terms following each 
Rua have their meaning. Thus $p u k e n g a=$ teacher, $p u k e=$ to rise, or increase, as water increases in volume during a freshet. Horahor $\alpha$ is from hora $=$ to expand. Wanawana is from wana, to bud or shoot, as a plant does, the budding out of the human mind being here personified.

The two Rongomai are two of the supernatural beings known as whatu kura, attendants of Io, the Supreme Being, in the uppermost of the twelve heavens. They serve as messengers, or rather as supervisors, for they are sent to inspect, and report upon the conditions of, all worlds or realms of the universe, and such reports are conveyed to Io.

Tupai was a man who dwelt in one of the Society Isles, Eastern Polynesia, at a time when the ancestors of the Maori were living there. He was in a house of learning when scholars were being taught therein, and, though not one of them, used his ears so well that he learned more than any one of them, hence his name of Tupai, the listener to occult teaching.

The Crown of the Heavens denotes the uppermost heaven, wherein dwells Io the mighty.

Now the subject changes, and, in connection with the good products presented to the child, Rongo-marae-roa, the tutelary deity, or personification of the sweet potato (the principal cultivated food product of the Maori), is invoked to cause a bounteous harvest. Rongo was one of the offspring of the primal parents, and is spoken of as the origin or parent of that tuber. All of the seventy members of that offspring produced something.

Poutu-i-te-rangi is the name of a star, the rising of which marks the commencement of the planting season. He embraces Puke-hau-one (or ahu-one), personified form of the husbandman's art, the forming of the little mounds of earth in which the kumara was planted, which means that the soil is prepared for the crop. Now enters Hine-rau-wharangi, a feminine personification of growth in the vegetable kingdom. The next lines call upon Rongo to fill the puke or little mounds with a plentiful crop, which will naturally result in a good supply of food for the Maruaroa season, late autumn, and the new year, which began with the heliacal rising of the Pleiades in June, among the east cuast tribes, but with the similar rising of Rigel in the northern part of the island.

In any such function where these gifts of food were not in evidence, the latter part of the above effusion was not repeated, for such would be an unauthorised act, a sort of force appeal to the gods. In such a case the speaker would chant the following :-

"List, O Son! By one sole power, the sacred power given by the gods, was Tane enabled to ascend unto the uppermost heaven; imparted by him to Huru-te-arangi, who, with Tonganui-kaea, produced Päräwera-nui, who clave to Tawhiri-matea, whose offspring were Titi-parauri, Titi-matanginui, and Titi-matakäkä, sent down to earth, hence the fresh breeze is felt, hence the whirlwind resounds; and now were the twelve heavens scaled,O Son!" 
Now as the reciter gave the foregoing, he carefully eliminated the part referring to Io, the reason of which is that he was among a large assembly of the people, hence he could not repeat that portion, it being too sacred. For no man might repeat the name of the Supreme Deity in any general or miscellaneous assembly of the people, or at any common or inappropriate place. But if he were reciting the above at the tuahu, or tapu spot (where many rites were performed, but only before a few privileged persons), then indeed he would repeat the whole. The part omitted is as follows :-

"List, O son! By one sole power, the sacred power given by the gods, was Tane enabled to ascend unto the uppermost heaven, where Io the Parentless alone was seen. His is the mighty, universal power; his the intense, unapproachable tapu; his the unattainable realm, his the welfare of all things. Then Tane attained to the baptismal waters of Puhao-rangi, forbear of Oho-mai-rangi; the cleansing waters of Hine-kauorohia . . . . . . Then Tane was called to the tapu place of Rehua at the end of the heavens, where all acquired knowledge was rendered permanent, the knowledge of portents, the knowledge of the gods; and Tane attained the thoughts of the gods, the enduring knowledge conveyed to this world, to be here retained as a guide for all on earth,-O son!"

Under no circumstances would this portion be recited before a miscellaneous assembly of the people.

Here end these ceremonial utterances by the speaker, who then addresses his remarks to the parents of the mother of the child, greeting and congratulating them in honorific terms; as also any other near relatives of mature age who may chance to be present; and then the people generally, winding up with the remark :- "You have heard the name of our grandchild; it is for you to recite the final hiringa."

This expression hiringa is often employed in these ritual functions, and implies assiduousness, and self-inspiration, as also the imparting of such qualities by means of such formulæ as those above given. This was a common practice among the Maori, more especially in regard to children, for such religious utterances were firmly believed to have the effect desired and intended, vir, the opening of the mind, to render it absorbent and retentive, to endow it with energy, determination, and a desire for the higher forms of knowledge.

Now, the speech-making by the members of the father's family having concluded, there rises a male relative of the mother, whose first act is to chant the short song known as Whakaaraara pa:-

"Awake and rise! The birds are on their perches; the sound of their singing strikes upon the ear. Awake and rise!"

The object in chanting this is to attract the attention of the people, to make them attentive, and cause them to confine their thoughts to the ritual about to be 
chanted by the orator, the subject being a serious one, and the ceremonial of a religious nature. The short preliminary chant was also employed for the same purpose during the performance of a very singular ceremonial pertaining to the construction of a new $p a$, or fortified place.

The speaker, while delivering the above, stands immediately before the mother, facing the people. Having completed it, he advances to the group composed of the mother's relatives, and, standing in front of them, he faces the other group, the father's clan, while he chants the following :-

"Now do I project my mystic charm toward the gods of earth and heaven, the far-reaching power of Tu-mata-uenga. My charm is the magic power of Tane, by means of which he scaled the interspaced heavens, to the realm of life, the primal realm, the forbidden place where spiritual life is. Abide, living spirit."

This utterance, of which the above is a very rude paraphrase, is supposed to have great effect on the mentality of the child, as also on its spiritual welfare. The final line reads "Tithe mauri ora"-sneeze living soul; it is a reference to the first sign of life in the first woman, the Earth-formed Maid. When the spirit or soul, and the breath of life, were implanted in the figure of earth, behold it sneezed, breathed, and opened its eyes,-a thing endowed with human life, a person, a woman.

Tu-mata-uenga was one of the offspring of the primal parents; male children were dedicated to him. These effusions seem crude in our wretched renderings, but to explain their inner meaning would mean an extremely lengthy dissertation.

Having concluded his utterance, rendered in the manner peculiar to the Maori, which we scarcely know whether to style a recitation or a chant, the speaker exercises his agility, while his whole audience join in the following pæan :-

"Living soul of this world, of the world of light,-

O son!"

Meanwhile the first speaker has again risen, joined the second speaker, and the two continue the acrobatic performance described above, always facing the people.

After this, the second speaker has the field again, and recites the formula already given at p. 141, on the completion of which the whole of the people rise and chant the pæan :-

"Welcome, O son!

Welcome, $\mathrm{O}$ son!

To this world, to the world of light."

The speaker then seats himself. The important part of the ceremonial is over; the above is the climax of the greeting and welcoming of the child into the world; others may now greet child and people in ordinary speech, but the ritual is over.

VOL. XLIV. 
Now the father of one of the parents (but not the father himself) will rise and greet child and mother. Then if the paternal grandfather of the child, he will greet the mother's folk, then address his own family group. The maternal grandfather would address the other side first. There is an amazing amount of punctiliousness exhibited at such functions among the Maori.

This is the end of the ceremonial known as the Koroingo or Maioha. The latter word means to greet with affection, while the former describes the peculiar whining, whimpering sound emitted by the Maori when desirous of expressing sympathy. It is somewhat unpleasant to cur ears.

A feast is, of course, provided for the persons who attend the above function.

\section{The Tohi Rite.}

The second ceremonial performed over the child has now to be described, and there is much detail to relate, as contained in the account given us. These minute details may not be of much interest to readers; we insert them as an illustration of the extent to which ritualistic customs are carried by a comparatively primitive folk, to show the inner working of one of the many religious ceremonies of the Maori.

In the first case we may remark that the grand ceremonial feast is not partaken of at the function already described, but after the Tohi rite has been performed.

After the Koroingo function, both mother and child remain in the "nest house" until the pito or cord has fallen off, which occurs about the eighth day after birth, whereupon the child is taken to the water in order to undergo the Tohi, in fact to be baptized. In no wise can the ceremony be performed prior to the falling off of the cord (iho or pito); the Maori folk were ever most particular in regard to this matter. The female attendants announce the fact, and the information is conveyed to the priest, who will say :-

"To-morrow, when Tama-nui-te-ra is high up, the child will be taken to the wai-matua that the Tohi ceremony may be performed over it."

Tama-nui-te-ra is the personified form of the sun, a term not used in ordinary discourse, wherein $r a=$ sun. Wai matua is a term applied to fresh water, in full "the wai matua of Tuapapa," but is not a common expression, such terms being employed only by what one might term educated persons (if such a term be admissible). The name Tuapapa seems to denote stratified rock, while Rakahore is the personified form of stones generally, as also the progenitor of such. In Maori myth Rakahore has two wives, who produce stones and rock. The Maori says that, were there no rock, water would not flow out of the earth, it would soak inwards. On this belief is based an old time aphorism :-

\section{"E kore a Parawhenua e haere ki te kore a Rakahore."}

Parawhenua would not move abroad were it not for Rakahore, i.e., there would 
be no flood waters were it not for rocks. Parawhenua-mea (in full) is the personified form of flood waters.

To return to our subject. At break of day next morning, the chief priest will dispatch one or two persons, probably priests of inferior rank, to select a place whereat to perform the Tohinga, or Tohi rite. A secluded spot is chosen, some place not likely to be used or trespassed on by people, a place where there is a suitable body of water, with suitable site, with proper aspect, whereon to arrange the ceremonial. The chief priest then informs the paternal and maternal grandfathers of the child (or, if these be dead, then uncles of parents) as to when the ceremony will be performed, saying:-

"At such a time our grandchild will be tohia; provide a parauai (fine cloak) for our grandchild to recline on."

The next act is the preparation of the place where the ceremony is to be performed. The chief priest and one of lesser rank proceed to the spot, as also the two grandparents above mentioned, the latter bearing with them a fine mat, such as is used for sleeping on, and two superior garments. If the child be a male, those garments will probably be a paepaeroa and a mahiti, the former a cloak of fine texture, made of phormium fibre, and having a deep ornamental border; the latter a cape covered with long dog's hair.

Under the supervision of the chief priest, the two grandparents arranged the paparoc, or place of honour for the parents. The fine mat was spread on the earth so that one edge was close to the edge of the water, be it 'stream or pond. The paepaeroa cloak was spread on the top of the mat, and then the mahiti cape on top of that again. The cape being smaller than the cloak, left the highly ornamented borders of the latter exposed to view. In both cases, the $u a$, or upper parts, collars, of the garments, were placed next the water side. Both these are superior garments, worn only by persons of rank. The cape termed a mahiti had a ground of phormium fibre, on which were arranged little tufts of long hair taken from the tail of the kuri maori, or native dog. Each such tuft was a small piece of skin stripped from the tail with hair attached. In some cases all were white, in others one tuft of white and one of coloured hair were tied neatly together and attached to the cape. The ornamental geometric patterns of the cloak borders were worked in black, red, and white. Having arranged the paparoa, the two grandparents retired to take part in the procession, while the two priests prepared for their part in the performance; such preparation for religious ceremonial in Maoriland seems to have principally consisted in taking off all one's garments, and donning a scanty apron.

The procession that accompanies the child to the scene of operations starts from the " nest house," which the mother and child now leave for good. She is accompanied by two special female attendants, one of her own family, and one of her husband's family. One of these walks in front, then comes the mother, then follows the other female attendant, then comes the father, carrying the child in his arms. After him follow the grandparents of the child, of both sexes, but no others 
are allowed to attend or witness the ceremony. The function is of the severest type of tapu, for the name of Io, the Supreme Deity, is to be uttered.

The two priests are ready to commence the ceremony on the arrival of the procession, each being naked, save for the scanty maro, or apron.

The head of the procession is now close to the paparoa, and the chief priest enters the water, advancing until the water reaches as high as his navel. The other priest stands on the right side of the paparoa, which is so arranged that the persons who stand thereon facing the water have their faces toward the east; thus the chief priest is on the eastern side of the paparoa as he stands in the water, and the lesser priest on the south side of it.

The chief priest takes his stand in the water while performing this rite because he has to repeat the name of Io, the Supreme Being, and because of the intense tapu pertaining to the ritual. His position in the water was the "cleanest" to be found, in Maori eyes, with the least possibility of his being affected by polluting influences; he was, as it were, spiritually insulated for the time being, and the act was also viewed as an honouring of Io. In the ceremonial performed over a sick person, certain ritual pertaining to Io was recited in the water, and, if the patient recovered, he was taken into the water, and a ceremony performed over him. The origin of this action lies in far back times, ere man was, when Tane had to undergo the Tohi rite twice before he could enter the realm of Io.

Now, when the head of the procession reaches the paparoa, the foremost person, one of the female companions of the child's mother, passes behind (west of) the paparoa and stands immediately behind the priest on the south side of it. Then the mother advances direct to the paparoa, steps upon it, and takes her stand in the middle thereof, that is in the centre of the cape. Then the other female attendant takes her stand on the left side (north side) of the paparoa. Then the father, bearing the child, advances, passes behind the mat, along the right side of it, and steps on to the paparoa beside his wife, who is the only one to advance directly on to it. Then advances the paternal grandfather of the child, who bears with him the $i$ ho of the child (the piece of the umbilical cord that has dropped off), who takes his stand immediately behind the father, but not on the paparoa. Then the maternal grandfather takes up a position just behind the female attendant on the left side of the paparoa. Then the two grandmothers advance, and stand behind, i.e., west of, the paparoa. Thus, all are in position, and it will be noted that the parents and child are the only persons who occupy the paparoa; which arrangement is all in honour of the child.

The father then hands the child over to the mother, so holding it that it is passed head first, and the mother clasps the child to her, its head against her breast, and facing outwards, for all of these persons must face the priest standing in the water, which means that they are facing eastward.

Now the chief priest, he in the water, is known as the tohunga tohi ora, while the priest of lesser rank stationed to the right of the paparoa is termed the tohunga whakairi; such are their titles during the performance of the rite. 
The latter priest now stretches forth his hand to receive the iho of the child, which was carried hither by the paternal grandfather of the child, but which, were the child a female, would have been carried by the maternal grandfather. The itho is contained in a small receptacle made of raupo (bulrush) leaves or juncus (rush) plaited. This receptacle had a special name which is now forgotten. This is handed over by the bearer to the priest. At the moment that the receptacle touches the hand of priest No. 2, the chief priest commences to recite the following :-

"On high let crashing thunder roar, 'tis Takamaitu, Taka-mai-i-awhea, and Taka-mai-te-ahurangi. Here am I, a proper child, a male child, of Io the Parentless, of the origin, of the acme of godlike power, of the powers of the heavens, and of Papa the Parentless. . . . Let godlike powers and mentality rest upon this child; a descendant of thy godlike offspring, O Rangi!"

The terms Taka-maitu, etc., represent personified forms of thunder. The first implies one loud crash; the second, the thunder that seems to rumble round the heavens; the third, either two or three loud reports. Papa is the Earth Mother; Rangi the Sky Parent.

As the priest concludes this recital, he dips a little water up in his right hand, and sprinkles it over the parents, as they stand on the paparoa at the edge of the water. He then continues:-

"The influential $i h o$, the important $i \hbar o$, the parental $i \hbar c$, to thee, O Io . . Io the unseen, the origin and the acme at Tiritiri-o-Matangi."

Tiritiri-o-Matangi is the name of the eleventh heaven.

At this juncture, says our informant, thunder would resound, without fail.

The last recitation is said to signify that the priest offers back, as it were, all the supernormal powers, knowledge, etc., that he has tampered with, deprecating his own temerity in interfering with such, a self-abasement. Quite possibly Tiritiri-o-Matangi should be Tikitiki-o-rangi, the topmost heaven, the abode of Io.

The secondary priest then hands the iho (cord), in its little casket, to the chief priest, who receives it in his right hand, slips it into the water, repeating as he does so-

"Uplift, uplift on high the influential iho, the important iho, the parental iho of this child . . . . to thee, O Io of all knowledge, of Tikitiki-o-rangi."

The last expression is the name of the uppermost of the twelve heavens. Where the blank space . . . . appears, the child's name was repeated, the priest having already been made acquainted with it. Not only the parents, but also other elatives of the child would have a voice in the decision of a name.

The secondary priest, on the land, now stretches forth his left hand for the iho in its receptacle. The chief priest shifts it into his left hand, and hands it to him. The latter then hands it to the father of the child, who holds it on his open hand which is extended towards the chief priest. 
The secondary priest then puts forth his open hands to take the child, which is laid with its head on his left hand, while his right supports its legs, so that, when he raises the child into a more upright position, much of its weight comes on his right hand, the hand that emblemises strength, and is termed the " male hand." Were the child a female, then its position on the priest's hands would be reversed, its head would be placed on his right hand, for the left is termed the "female hand."

This priest then turns and faces the chief priest, repeating as he does so these words :-

"May all evils, all misfortunes, be warded from this child, $\mathrm{O}$ Io the Parentless."

As the secondary priest utters these words, he is advancing towards the chief priest through the water, bearing the child with him. As he repeats the last word, he reaches the priest, and places the child on his hands, so that the head of the child rests on his left hand, and the legs on the right. The chief priest then recites the following :-

"Welcome, O son! Be eminent in noble knowledge, excel thyself in useful arts; thus shall all wisdom be permanently acquired. Come, O son! Grasp the three baskets of occult knowledge, for which Tane ascended by the whirlwind to the entrance of the uppermost heaven; when he appealed to Huru-te-arangi, who with Tonganui-kaea, produced Päräwera-nui, who mated with Tawhiri-matea, and sent their offspring hither, and hence is felt the freshening breeze, and heard the whirling winds; for now were the twelve heavens attained, $\mathrm{O}$ son!"

As the priest finishes his repetition of the above, he raises his left hand so as to raise the head of the child, and then stoops so as to sink his own body in the water, until the water reaches the neck of the child. He then clasps the child to his breast with his left hand, its head resting against the upper arm. With his freed right hand, he then sprinkles a little water on the head of the child. He then rises again, and once more stands upright, while he repeats the charm to cause thunder to sound, "and the living soul, that is to say, the thunder, resounds."

Now, should that thunder resound toward the east, or the north, it is accepted as a good omen, the child will be healthy and vigorous; if toward the south or west, then misfortune lies before the child. If the thunder resounds in the south, he will probably not attain manhood.

The child is then handed over to the mother. The two parents step off the paparoa, and the priests turn the mat over so as to double it, with the two garments enclosed, so as to expose the ground beneath. The chief priest takes a stake about six feet long, sharpened to a point at one end, the same having been made for the occasion, and proceeds to make a hole in the ground in the centre of the spot that had been covered by the mat. He forms this hole in the usual Maori manner, as 
when making a fence, by plunging the pointed end of the stake into the soil, then working it round in the hole so as to increase the diameter thereof, then plunging it in again, repeating this process until the hole is deep enough. The priest then takes the $i h o$ (cord) from the hand of the father, and places it in the hole, which he does with his right hand. He then reverses his tool and tamps the earth into the hole with the big end thereof, so as partially to fill the hole. He then puts some stones into the hole, that is, he places therein one stone for each night (day) that the mother was in labour with the child. He then tamps more earth in so as to cover the stones and fill the hole. As he does so he recites :-

"Completed at Whare-rangi was the attainment of knowledge. The medium of the sacred Tohi was Apa-i-te-ihonga."

This is a doubtful rendering, but the original is a puzzler. Whare-rangi was the abode of Tane and others of the offspring of the primal parents. The Apa mentioned was one of the attendants of Io in the uppermost heaven. The above recitation applies to the stones buried. But should the nights of labour extend to ten, then no stones are buried, for the child is going to be of a disagreeable disposition, and so also would the stones be! Nor would priests consent to stones being so buried for a stillborn child. The iho or pito is buried as a sign or proof, and the place where it was so deposited would ever after be known as the Iho of So-and-so. We know of many such place names, and but a few years ago saw an iho buried on the summit of a small hill near the parents' residence, the mother being one of the owners of that land, otherwise it would not have been deposited there. The spot was marked with a wooden post firmly inserted in the earth. In this case there was, we believe, no Tohi ceremony performed. It seems to have fallen into desuetude.

Should a dispute arise at any time concerning the land whereon an iho is buried, as over a boundary, or over the mana (authority of ownership) of a person or gens over such land, then the fact of such iho being buried is as good as a Crown Grant, and, as it is a perishable object, the stones are sought, and accepted as a proof. They were also referred to on more trivial occasions than the above.

One of our most learned men of the middle decades of last century, Te Matorohanga, of Wai-rarapa, informed his pupils that some tribes, Tuhoe for one, used to make human sacrifice at the Tohi ceremony, but that the Takitimu tribes never followed this custom (though a survival of it appears to have been retained, unrecognized as such by the natives). He said that the act of placing the child's head on a weapon (see post, p. 156) implied "he arai $i$ te patu tangata," a forbidding of man slaying. Thus it seems to have been a custom formulated to put an end to human sacrifice on such occasions. The weapon took the place of the human sacrifice, and imparted a certain amount of eclat to the ceremony, which seems to have been the main object in a good many cases of human sacrifice among the Maori. This is an interesting illustration of culture development among a primitive and isolated folk, this abolishing of such a sacrifice on the above 
occasion. Curiously enough, we are only now beginning to grasp the fact of the superior culture of the Takitimu tribes of the east coast.

In cases where such sacrifice was made in connection with the Tohi rite, the priests are said to have selected the victim. The object of the act was to enhance the prestige of the child, and of the ceremony performed over it, to render both more important in the public eye, likewise to impart to the child the fame, prestige, power, of courage and chieftainship. Men only were sacrificed on such occasions.

Some tribes, again, merely performed the Tohi and held a ceremonial feast, without any presents being made, and no paparoa was provided for the parents to stand on.

The elaborate form of Tohi described above is termed a Tohi ariki. That in which a human sacrifice was made, is a Tohi raupara; while the inferior form of ceremony, minus sacrifice, presents and paparoa, and, in some cases possibly with no appropriate feast, is known as a Tohi kura.

It is said that the inferior class of natives (a dangerous expression, for we never saw a native who would admit that he was a member of an inferior class) employed the Tohi kura grade of the ceremony. Now, the Tohi ariki was always performed at the proper time soon after birth, but the Tohi kura might be postponed and performed years after birth. This postponement might be owing to poverty on the part of the parents, a lack of food, or of presents, or to the death of the father. Cases have been known wherein a person was not tohia until he attained manhood and was tattooed. Such a belated performance might be owing to such jeering remarks as "Who are you? At what water were you tohia?" Or to a feeling of shame when asked such a simple question as- "Where were you tohia?"

We will now return to our Tohi ariki party at water side, and see to the return of the party to the village, for the Tohi ceremony is now over, and the party is about to form a procession and march back not to the "nest house," but to the village, where the Pure ceremony is to be performed before the principal house of the hamlet, or fortified village.

The burial of the stones being completed, the priest picks up the paepaeroa cloak and places it across the shoulders of the father of the child, and then puts the dog-skin cape over it. The father then takes the child from the mother, and holds it with his right arm, drawing the cloak over the child with his left hand. The procession then re-forms for the return, but now the father precedes the mother, carrying the child, and followed by the mother. Then come the grandmothers of the child, then the grandfathers, then the two female attendants. Prior to starting, the chief priest steps forward and places himself in front of the father, thus heading the column, while the inferior priest brings up the rear. The procession then moves off, advancing slowly to the village home, while the chief priest chants the following in a loud voice :-

“Awake and rise," etc. (see ante, p. 144). 
The people at the village hear the voice of the priest chanting the above, and know that the ceremony is now over. The chant has notified them.

Now, should the manner in which the thunder resounded have betokened an ominous future for the child, then the above is not chanted by the priest, but he recites the following in its place:-

"Now eager are we to perform the task before us, to ignore and baffle the evil omen .... to protect the tapu. For I am tapu, and elated through the Parent One, the warder off of evil, the guardian of welfare. Ye shall not be affected by the evils, of this world, etc."

The object of this charm is to ward off the effects of the evil omen of the thunder, and to preserve the child from harm. The priest thus notifies the people that he will not accept the omen quietly, but will do all in his power to baffle or avert it. The meaning of the words of the charm is obscure, hence we curtail it.

While the Tohi rite was being performed, the bulk of the people were busy in making preparations for the ceremonial feast with which the proceedings wound up.

Now there is another act of divination that was at least sometimes performed during the Tohi ceremony, but it is not certain that it was always done, probably not. There was also another mode of baptising, i.e., sprinkling the child. Both of these items, which seem to have been local variations, we give here-

When the chief priest enters the water, he takes with him a small green branchlet of mapau (Myrsine Urvillei) or tawhiri (Pittosporum tenuifolium), if easily procurable, these being used in divers ritual performances, as also were Piper excelsum and Coprosma robusta. He also has six pieces of the young, unexpanded heart-leaves of some plant. We are informed that the old or outer leaves would not serve the purpose. He enters the water, and, when the people are in their places, he advances towards the mother, reciting his karakia, or ritual, as he advances, until he is close to her, as she stands on the paparoa with the child in her arms. The priest touches the child with the branchlet, and then, dipping it into the water, sprinkles drops of water from its leaves on to the child, still repeating his ritual, and sprinkling the child at a certain part thereof. It is believed that water is so employed in this ceremony because it is one of the principal elements of life, or that support life, apparently the most important one according to Maori ideas. For it was taught of old that "Water is the life of all things ; without water nothing could flourish."

Having so baptised the child, the priest casts the six pieces of grass or leaves into the stream, and the movements of these are carefully watched. Should they drift away without scattering or separating much, the fact is hailed with pleasure, it being a good omen for the child's future, he will be healthy, vigorous, clever, and will attain manhood. But should the pieces separate, and drift apart, the omen is a bad one for the child.

It is probable that the number of pieces of herbage used in this act of 
divination was not confined to six, for there is some evidence to show that the pieces equalled in number the stones buried with the iho; but this is not assured.

Yet another variation in the baptism consists of a sprinkling of the child by the hand of the priest, no branchlet being used, after which he again dipped his hand in the water, and passed it across the child's face, as he repeated :-

"Be diligent in the performance of ritual. Be exact in thought and act. Enjoy well-being, O soul, in this world, the world of light."

\section{The Pure Rite.}

Ere the procession has reached the village, preparations have been made for the final ceremony, known as the Pure. The porch of the principal or largest house of the hamlet was prepared in much the same way as the paparoa for the Tohi rite. An ordinary floor-mat was spread in the porch, and over it a finely woven mat, termed a takapau-rangi, ornamented with woven patterns, was laid. These mats were laid to the right of the doorway, opposite the window. The taonga, or gifts, were displayed on these mats. Any garments, such as cloaks and capes, were spread with the upper part towards the window of the house. If a special honouring of the child is intended, then a nephrite or whalebone patu (a short weapon) is deposited on the top of the cloaks, below the $u a$ or neck-band. If two such weapons are so deposited, they would be laid with the butt ends together, and the blades outwards. If there chanced to be among the items a taiaha (a highly prized carved weapon, used also as a baton), it would be laid on the upper part of the cloaks. These are the only forms of weapons so displayed, being the most highly prized; the hoeroa, pounui and others are thought much less of. This is one of the reasons why the patu and taiaha are valued so highly, because of their being used in ceremonial functions. A carved box to contain plumes might also be included among the above items.

The procession now arrives at the plaza of the village, the priest still chanting his ritual, which he will repeat several times over, until the procession halts on the plaza. The party halts near the outer plank of the porch. The priest takes his stand by the post of the facing board of the gable, while the parents of the child proceed straight towards the window, and, when the priest says :- " Step on to the tahuaroa," the husband steps on to the spread cloaks, turns and faces outwards, while his wife seats herself to the right of her husband, but not on the tahuaroa, i.e., not on the cloaks, she remains on the projecting mat at one side.

Now, as the party were approaching the plaza, the people at the village were all assembled, and engaged in crying a welcome, even until the procession halted. This welcome was given in the vociferous Maori manner, and was accompanied by weeping, in which those of the procession following the parents joined, but whose greeting would be described by the honorific term whakaingo, not by the ordinary word tangi. Should anyone apply the latter term to it, then it would be compared to weeping for the dead. 
Enough; the husband is facing outward, his wife sitting at his right hand. The paternal grandparent then steps on to the mat near the husband, but does not trespass on the tahuaroa. The husband pulls his cloak round until the opening thereof is in front, holding the child against his breast. The priest, standing by the post, recites the ritual given on p. 142, commencing "Welcome, O son! Hold fast to the sacred teaching," etc. He then repeats the following :-

"Welcome, O son!

Be ye wise and clever as Tane-matua, he who elevated and be-spaced the twelve heavens, when awe and fear was felt in the presence of mighty things. Then came into being the clouds and heavenly bodies, all things on earth and in ocean . . . . and became truly permanent and everlasting; even to the gods of this world, to Rongomai-tuwaho, to Rongomai-whakateka, possessed, through Tane-matua, of the 'baskets' of knowledge wherefrom to chose, given by Tuhae-pawa and Io the Parentless, fixed and unalterable for all time. Then is the soul caught by Hine-titama to the Underworld,-O son!"

Rongomai-tuwaho is said to personify space, and Rongomai-whakateka the evil gods or demons of this world. Tuhae-pawa is one of the attendants of Io in the uppermost heaven. Hine-titama became Hine-nui-te-po, goddess of the Underworld.

The people now approach the porch and greet the child with words and song and tears, for this is the final greeting. When this greeting and crying is over, speeches are made, the principal sentence of which will be:- "Welcome, O son! Ye who come from within the wai matua" (sce $\mathrm{p}$ 146). For this is an old, old greeting to a child just brought from the waters where the Tohi rite has been performed over it.

The persons who attended the Tohi or baptismal rite have the tapu removed from them by the priest, it may be at the turuma (latrine), or, in special cases, such as the one we are describing, at some pool of water.

The ceremonial being now over, the people partook of the ceremonial feast (hakari), for which food supplies in great quantity and variety would have been prepared. At such a function, the food for the priest was cooked in a separate oven, termed an umu tär $\ddot{a}$, while ovens (steam earth-ovens) in which food for the bulk of the people was prepared, are called umu rauroha.

A mat is spread on the ground outside the porch in which the parents hare been seated, as a separate place for them. Seating themselves upon the mat, food is placed before them, but they cannot help themselves thereto, each parent has to be fed by one of the taputi, or female attendants, described above. This condition of tapu, however, does not extend beyond that day. On that day it would not be right for their hands to touch any article of food, hence it has to be placed in their mouths by the attendants. For such are the customs of the Maori.

When the parents left the porch in order to partake of the feast, the child 
was laid upon the cloaks, with its head on one of the patu, or weapons. This implies that the child is tapu, and will remain so; will be reared with special care as a person of high rank, and will at no time be allowed to carry food supplies on his back, his back and head being under special tapu for life. He will always be allotted the sleeping place under the window, on the right-hand side as you enter a native house. Also, when visiting other places, he will be given that position in any house he occupies. For his tapu is that of an ariki, or high chief, it is hereditary; it is not as the tapu of a priest, for the latter may be said to pronounce his own tapu. The tapu of the child under discussion was much intensified by the performance of the baptismal ritual over him at the wai matua, or stream, and the fame of that ceremony would extend to all parts and to all surrounding tribes. Hence, when travelling, albeit in his old age, on arriving at distant places his fame would have preceded him, and a place prepared for him near the window of the guest's house, while each chief of the place would present him with some special dainty in the way of food, which would be laid before him. Nothing in the way of food would be withheld from, or considered too good for such a guest. This act has two aspects : it is viewed as an honouring of the guest, and also an honouring of the local marae or plaza (reception place). The reputation of the latter for generosity and punctilious conduct towards a noted guest has been maintained, that is to say the reputation of the local people.

Female children of high rank were sometimes accorded this higher form of the Tohi ritual, notable cases being Tamairangi of the Wellington district, Hine-matioro of Titirangi $p a$ at Uawa, and Mahina-rangi ; all were chieftainesses of the Takitimu folk, and were treated with great respect by the east coast clans.

The last person to undergo the above ritual on the east coast, so far as is known to our informant, was Karauria, father of Airini, and the ceremony took place about the year 1846. It was performed at the little islet of Tapu-te-ranga, at Te Whanga-nui-a-Orotu (the inner harbour of Napier). Our informant, then a child, was not allowed to be present at the rite, and naïvely remarks that, although in the vicinity, he did not hear the rolling of thunder on that occasion.

Priests who officiated at any ceremonies such as the above, were not paid for their services according to any bargain made, but gifts would be made to them. In some cases, it is said, no such gift might be made after the ceremonies above described, but such offerings would be deferred until the pokanga taringa, or ear piercing, that is when the child's ears were pierced by the priest that pendant ornaments might be suspended therefrom. This would be performed when the child was about four years old, possibly somewhat less. But, as soon as the child could run about, a pendant, possibly of nephrite, would be suspended from its neck, at least on "company occasions." When the ear piercing was over, and it was a ceremonial affair in the case of the child. of a person of importance, such a prized pendant might be taken from its neck and presented to the priest who had performed the various rites over the child. Such a gift might be supplemented with a fine cloak, in which case the cloak would be laid before the recipient, and 
the ornament laid upon it. In presenting a gift to a person, the Maori does not put the object in his hands, but places it on the ground before hirn. As a rule, priests received the finest presents, and when several were to be recompensed, the gifts were placed before the chief priest, who gave some of them to his assistants.

The implement employed to pierce the ears would be made of albatross bone, or of human bone. In the latter case, it would be made from the bone of an enemy, and it would be known by the name of that enemy. This latter kind, it is said, were preferred for piercing the ears of a boy. Hence, if a young man's ear pendant hung well, one might ask the question: "Whose bone was it by which your ear was pierced?"-whereupon the answer might be - " $E$ ! He toroa a rura" (O! It was an albatross bone).

In regard to the general object of the various religious ceremonies we have described, the main idea seems to have been to endow the child with manc atica, supernatural power or attributes, such as the gods possess, the divine powers that emanated from Io, as also with intellectuality, etc. Absurd as it may seem to us, the Maori believes that, to some extent, man can possess such attributes. The ritual also implied a recognition of the existence of Io and of his majesty; of a belief in his power, and of the efficacy of any ritual, properly carried out, that pertained to him.

Now the different names of Io have each their own distinct meaning and application, and each is employed in its proper connection only. Thus, in the Tohi ariki rite, described above, the name of Io-matua is the one pronounced. In the Tohi taua rite, pertaining to war, the name used is Io-matakaka. In a ceremony performed in order to implant mental ability, etc., in a child, the name used was Io-mataaho, while in another performed over pupils entering the whare wananga, or school of occult learning, the name of Io-te-wanga was the one pronounced. Each name of Io represents a certain quality.

In the singular legend of Uenuku-titi, the offspring of the wife of Tamatea (an historical personage) by a supernatural being, occurs the following:- " The Pure was performed over Uenuku-titi, and it was proposed to take her to the water and accomplish the Tohi"; but Tamatea said,

"No, her name has already been tohia by her father out on the ocean."

This looks like a different order in the arrangement of the ceremonies, and the extract contains a curious usage regarding the word tohi. This word seems to be used in an almost generic sense in regard to divers ceremonies, even as the terms pure and hou are, but does not necessarily mean a naming. The word tua, however, does mean "to name," and the Tohi rite we have described is known as the Tua ceremony among some tribes. Tohi also means " to cut," and some think that it applies to the eutting of the navel string; and it may have been so originally, though it now seems to be used in a different sense.

In the same legend, Uenuku, the semi-divine person, asks for food, and is told that there is none prepared- "Then whăt is that I see covered yonder, and from 
which steam arises?" replied her mother. "That is an oven of special food connected with the Tua rite which is about to be performed over your brother." Whereupon Tamatea said- "Uncover the oven, and let her eat the food." The reason for this extraordinary remark was the fact that Uenuku was the elder of her mother's children, hence she took precedence over her brother. No other person would have been allowed to partake of that food.

The term pure does not necessarily mean a removal of tapu, as is sometimes stated. Often it had the opposite effect. A Pure rite was performed over a crop in order that a good harvest might result. Many things may be purea in order to bring them under the care of the gods, an act which renders them tapu. A man may be purea to cause him to bear himself well in battle; a canoe may be purea to preserve its mana, to cause the gods to attend to its welfare. Hence the pure ceremony is, in many cases, a rite to endow the subject with tapu attributes and supernatural mana (power).

The above comprises about all the notes gathered on the subject of birth rites from the Takitimu tribes, and is fairly complete, considering that the ceremonies described have long been abolished. That some discrepancies exist between different statements made by our native friends is evident, but such is ever the case in information concerning customs that are no longer kept up, and the knowledge of which has of late been preserved orally without the special care displayed in such preservation in old Maori times.

It is interesting to note the importance of the $i h o$, the portion of the umbilical cord, in the eyes of the Maori. The ordinary meaning of the word iho is kernel, core, or very centre.

The curious ceremony known as oho rangi is also of interest. The Maori firmly believes that the priests of former times possessed powers over the elements, and that they could cause thunder to resound. Several forms of ritual are said to have concluded with this performance. In such supernormal manifestations it is not the direct powers of the priest that produce them, but the ritual of the priest induces the gods to produce the desired effect. This seems to be the belief at the back of the native mind. The successful performance of this act would impart power and effectiveness to any ceremonial, such as the Tohi, over a child, or to a rite performed in order to restore a sick person to health.

In regard to the underworld to which descend spirits of the dead, as mentioned above, we wish to make it quite clear that, in the old Maori belief, there is no suffering or unhappiness in the spirit world, and absolutely no punishment for the soul after death, no matter what the character or acts of a person in this world may have been. In a paraphrase of an old time ritual published a few years ago, two of our Maori linguists misconstrue a mention of the underworld, and speak of it as follows:-

"To realms infernal . . . . . here no light appears, no single gleam; an awful gloom for ever reigns: such is the darkness of that lower world of Night Eternal. Where deposed ${ }^{*}$ Whiro rules and grasps with fearsome 
clutch the passing dead. With horrid reptiles rules this dismal hell! . . . . These go to hell, the vilest spirits there . . . the place of sighs and groans."

Now the above is pure imagination. No word of these horrors is found in the original, nor in any other Maori song, myth, tradition or ritual. It was not a Maori belief, and we see in the myth of Mataora that life in the underworld was believed to be much purer and less gross than that of this world. The spirits of all sorts and conditions abode in the underworld. It may be all very well to be a good Christian, but why deliberately misrepresent the beliefs of another people, and credit them with a horrible myth which they never evolved or possessed, until we enlightened their ignorance.

\section{The Custom of Taumau, or Betrothal.}

The custom of betrothal (taumau or taunaha) in infancy was by no means uncommon among the Maori folk, and, as this occurred in some cases at the conclusion of the Pure ceremony over a newly-born child, we here give some account of it, as practised among the Takitimu tribes.

The Pure has been concluded; the ceremonial feast is over. A chief of the tribe, or possibly of another tribe, rises to speak, he says:- "My utterance: I bespeak our grandchild for ...."-here mentioning the name of a child of the opposite sex, and of his own clan. Now, neither the parents, nor yet any of the people will make any objection to this proposal of a betrothal, for such an act would be deemed a belittling, not only of the proposer and the child, but also of the whole clan of which they are members; it would be looked upon as an expression of contempt, and would assuredly cause trouble in the future. Supposing such an offer was refused, then, in the days that lie before, war might break out between the two peoples, and the child so asked for, be captured, in which case he would not be slain, but enslaved, that the stigma of slavery be attached to him, and the remark "a slave of mine" would be said of him, his descendants, and clan, down through generations of time. All kinds of trouble might emanate from such a refusal.

There is another point: if a well-born member of one tribe marries into another, he or she will act as a "cord" to draw that tribe to our assistance in war. The two tribes will call upon each other for assistance at such times.

In the event of a taunaha or bespeaking of a child being refused, the discomfited party would never expostulate, or argue about the matter. The spokesman would make one brief remark, in the form of an old time aphorism; he would rise and say :-

\section{"Waiho ra, e hika! He toi tipu te tangata, he toi heke."}

That saying implies the doubtfulness of the future in regard to human wellfare. One or both of the children may not reach maturity, and while behind that 
lies a hint that the refusers may regret their action in the future. In fact such a refusal is practically an insult, and is liable to bear bitter fruit in the future. "Mo a muri, mo a nehe"-the days that lie before will show.

Such a taunaha or bespeaking of a child may not take place for some time after the performance of the ceremonies described above, even years after; there is no fixed time for such a function.

We often hear interesting references to old customs in evidence given by witnesses before the native Land Court, as when, during the hearing of the case of Nga Waka-a-Kupe block, a witness remarked-“"When Hikawera was born, he was bespoke by Rangitane for Waiutukura. They were (eventually) married in the house (named) Huruhuru-rautara, at Whata-manga."

When the Maori folk first saw the European method of baptising children, they did not approve of it; the general remark was ".Kaore $i$ hangai," meaning that it was not correctly done, it did not agree with ancient custom; the wai matua in Nature's own font is the only proper place at which to perform such a ceremony. As performed by the white folks, it is much more common, and less tapu.

The Takitimu natives have preserved an extremely old and fine invocation to Io that was recited during the Tohi ceremonial over the famous ancestor Toi, who flourished about thirty generations ago. We regret being unable to render it into English, so archaic is its form, and of so eryptic a nature its wording.

We have stated that we do not propose to insert in this account any information on the subject gathered from other tribes, inasmuch as differences are often noted in the performance of ritual among different tribes, between whom there was but little communication, and such variations would probably lead to confusion in the mind of the reader.

We now, however, propose to disregard that statement, to some extent, and insert a few notes collected many years ago by the late Mr. John White, in order that they may be placed on record.

Mr. White has a note in his MSS. to the effect that, among some tribes, a woman's father, or grandfather, or a tohunga (priest), would, in some cases, attend her during the period of parturition, and play upon a flute made from a bone of an ancestor of the woman or her husband, until such time as the child was born. Such a flute was looked upon as a connecting link, or medium, between the living on the one hand, and their defunct elders and ancestors, as also the gods, on the other. As most gods of the Maori are ancestral deities, deified ancestors and spirit gods that care for, cherish, warn, admonish, and also punish, their living descendants in this world, the mediumistic idea and its advantages are fairly clear. The use of such a flute would be a medium in influencing ancestral spirits to assist the woman in her trouble. This performance with the flute is said to have also been gone through if the child was ill during infancy, as also when it was getting its teeth. It was not a common custom, however, and may even have been confined to one tribe, or a small area. It is much to be regretted that Mr. White did not record his authorities, or even the localities in which he obtained his innumerable notes on 
native customs, etc. This should be one of the principal cares of the collector of anthropological data.

The same authority says that, when a woman is in labour, she is attended by her parents. If she be apprehensive of trouble, or if any difficulty occurs, then a priest is called in to repeat a charm to cause the child to be born.

The child of a woman of good family is really tapu prior to birth, and such a woman would not be allowed to carry food on her back during the period she was in child. It may be explained here that in carrying burdens, the Maori straps them on his back, and does not use the balance pole of Eastern Polynesia.

As to the woman being attended by her parents, this custom was not followed among some tribes, or in many cases, as we have already seen.

The following brief notes concerning the Tua or Tohi ceremony were also collected by Mr. White, locality not stated.

About eight or ten days after the birth of the child, the pito fell off, whereupon both mother and child were conducted to the waterside, where the Tua rite was performed. One of the charms repeated over a male infant was termed the Whakangungu, and the object was to cause the child to develop into a courageous warrior and successful man-slayer, and man-eater. During the performance of the Tua ceremony, two pits were excavated near the waterside, each about two feet across, or less, and allowed to fill with water. These were termed the "male well" and "female well." Light objects were cast into these water-filled pits, from the movements of which objects on the surface of the water, certain auguries were derived by the priest concerning the future welfare, or otherwise, of the child. No details are given.

When the charm mentioned above was repeated over the child, a small reed or rush stem, to represent a weapon, was placed in his hand, the mother assisting the babe's hand to retain it. In the case of a female child, a small hank of dressed phormium fibre was so placed in her hand (the emblem of weaving). The pito was buried at the sacred place of the hamlet, and, on the return of the party to the village, a ceremonial feast was held.

Children were often so named as to commemorate some injury, defeat, or insult, sustained by the tribe, so as to keep green the memory of such wrongs.

Among the Ngati-Whatua tribe, the child was laid on a mat near the waterside. If the child were a male, the grandfather and uncles stood on the east side of the child during the ceremony, and the male cousins on the west side. A grandfather dipped a branch of Karamu (Coprosma robusta) in the water, and sprinkled the child therewith, while certain invocations were repeated, the officiating elder reciting certain portions thereof, and the cousins other portions. In the case of a female child, the grandmothers and aunts stood on the east side of the child, and the female cousins on the opposite side.

Infanticide was not infrequent among the Maori in former times, but it never assumed here the wholesale form that it had at Tahiti, and other isles of Polynesia.

More females than males were so slain, a female child not being so highly 
valued as a possible fighting man. A widow might so kill her child when she lost her husband, and wives sometimes did the same on receiving some slight or insult from their husbands.

We here conclude our somewhat rambling story, the account of birth ritual as practised by the Maori, ere the white man broke through the hanging sky and reached his lone isles. Interpolations have been many, and perchance tedious, yet so numerous are the inclusions of personifications, and allusions to old myths, in such matter, that explanations are imperative.

As for the crudeness of translations and collation, we will re-quote a maxim old as the days of Tane the Fertiliser and of the Earth-formed Maid:-

"E kore a Parawhenua e haere ki te kore a Rakahore."

In like manner-You of the world of light cannot compile your books without material. Your anthropological data are with us in the dark places of the earth, when we camp on the trail of primitive man, and drive our roads across the paparoa of his baptismal font.

In one respect are we on the same plane; for the three "baskets" of knowledge, obtained by Tane from Io, are open to all men alike. Each man must choose for himself the good or the evil.

Tike mauri ora! 